\title{
Pelibatan Peserta Didik melalui Metode Tajak Sare dalam Pembelajaran Daring
}

\author{
Jefri Soni \\ SMA Negeri Unggul Aceh Timur \\ jefrisoni@smanunggulatim.sch.id
}

\begin{abstract}
The purpose of the study was to increase the participation of learners in online learning using the tajak sare method. The subject in the study was a learner of MIPA 1's XII class of 26 people. Research design uses a class action research design of as many as 2 cycles. The action that was committed was the ascetic of applying tajak sare methods. This method stands for questioning, correction (reinforcement), information sharing and reps (repetition). The method focuses on the participation of learners on indicators of noticing lessons, asking and answering, giving rebuttals/opinions, and collecting tasks on time. Each cycle consists of 2 learning encounters through video conference. In the first cycle, the learner participation level is only 37.96\% classically and it increases to $64.35 \%$ in the second cycle. The magnitude of the increase between the two cycles is $26.39 \%$. The results of this study showed that the application of sare tajak methods in online learning through video conferences could improve learner participation.
\end{abstract}

Keywords: $\quad$ learner participation, learning methods, tajak sare, online learning, video conference

\begin{abstract}
Abstrak
Penelitian ini bertujuan untuk meningkatkan partisipasi peserta didik dalam pembelajaran daring dengan menggunakan metode tajak sare. Subjek dalam penelitian adalah peserta didik kelas XII MIPA 1 yang berjumlah 26 orang. Desain penelitian menggunakan rancangan penelitian tindakan kelas sebanyak 2 siklus. Tindakan yang dilakukan berupa penerapan metode tajak sare. Metode ini merupakan singkatan dari tanyajawab, koreksi (penguatan), sharing informasi dan repetisi (pengulangan). Metode ini berfokus pada partisipasi peserta didik pada indikator memperhatikan pelajaran, bertanya dan menjawab, memberikan sanggahan/ pendapat, dan mengumpulkan tugas tepat waktu. Pada setiap siklus terdiri dari 2 pertemuan pembelajaran melalui video conference. Pada siklus 1 tingkat partispasi belajar peserta didik adalah hanya sebesar 37.96\% secara klasikal dan pada siklus 2 meningkat menjadi 64.35\%. Besarnya peningkatan diantara dua siklus tersebut adalah 26.39\%. Dengan demikian hasil penelitian ini menunjukkan bahwa penerapan metode tajak sare dalam pembelajaran daring melalui video conference dapat meningkatkan partispasi belajar peserta didik.
\end{abstract}

Kata Kunci: partisipasi peserta didik, metode pembelajaran, tajak sare, pembelajaran daring, video conference 


\section{A. Pendahuluan}

Pandemi Covid-19 yang melanda sampai ke Indonesia pada awal tahun 2020 langsung berdampak besar pada dunia pendidikan terutama pada proses pembelajaran. Proses pembelajaran yang biasanya dilakukan dengan tatap muka diganti dengan Pembelajaran Jarak Jauh (PJJ). Pembelajaran jarak jauh merupakan model pembelajaran yang dilaksanakan untuk mengatasi perbedaan jarak, waktu, dan tempat dalam proses penyelenggaraan pendidikan (Artyana 2014). PJJ adalah pendidikan terbuka yang memberikan kesempatan kepada siapapun tidak pada usia tertentu, untuk memperoleh pendidikan, dari sumber belajar yang luas. Proses pembelajaran dapat dilakukan dari rumah (home based education) yang dibimbing dan dibina oleh orang tua atau anggota keluarga, atau pada lembaga pendidikan non formal. Hal ini dilakukan berdasarkan pada instruksi dari pemerintah melalui Surat Edaran Kemendikbud RI No. 4 Tahun 2020 tentang Pelaksanaan Kebijakan Pendidikan Dalam Masa Darurat Penyebaran Coronavirus Disease (Covid-19). Pelaksanaan PJJ dapat dilakukan dengan media dalam jaringan (daring) maupun luar jaringan (luring). Tujuan pelaksanaan PJJ salah satunya adalah memutus mata rantai penyebaran virus dan menjaga keamanan dan keselamatan peserta didik maupun tenaga pendidik (Zhafira, 2020).

Dalam menunjang PJJ ini dibutuhkan media pembelajaran yang digunakan untuk mempermudah penyampaian informasi dalam pembelajaran (Rinaldi et al., 2017). PJJ dapat disampaikan baik berbantuan teknologi sederhana maupun teknologi terkini seperti pemanfaatan internet atau dengan kata lain melalui luring ataupun daring. Pada sistem luring pembelajaran terlepas dari internet atau bersifat offline dengan menggunakan media perangkat ajar cetak dan elektronik. Pembelajaran daring merupakan pembelajaran dengan menggunakan platform yang dapat membantu proses belajar mengajar jarak jauh dan berbasis internet. Tujuannya ialah untuk memberikan layanan pembelajaran bermutu secara daring dan bersifat masif, serta terbuka untuk menjangkau banyaknya dan luasnya peminat ruang belajar (Sofyana \& Rozaq, 2019). 
Hal ini sesuai dengan pernyataan Crockett \& Foster (2005) bahwa proses PJJ dapat disampaikan dengan menggunakan berbagai teknik dan teknologi. Cara-cara penyampaian tersebut antara lain; Pertama, dengan menggunakan bahan-bahan tertulis. Bahan-bahan teks ditulis secara khusus untuk kursus, misalnya buku kerja (workbook) yang berisikan tugas dan latihan dengan durasi penyelesaian secara mandiri pada rentang waktu tertentu. Kedua, melalui program televisi yang dirancang untuk menyampaikan teknik-teknik dan teori. Ketiga, E-learning: penyampaian berbantuan komputer dengan memanfaatkan internet serta aplikasi yang mengarahkan peserta didik untuk berinteraksi dengan sumber belajar melalui chat room (ruang komunikasi), notice board (papan pengumuman), dan video conferencing

Sesuai uraian di atas Pemutusan rantai dalam pembelajaran online menggunakan skenario daring dan luring. Kebijakan yang diambil oleh SMA Negeri Unggul Aceh Timur adalah dengan skenario pembelajaran daring. Aplikasi yang digunakan adalah Learning Management System (LMS) dari Perusahaan Microsoft yaitu Microsoft Teams dan Microsoft Kaizala. Pembelajaran dilakukan secara sistemik dengan pembagian jadwal meeting atau konferensi video dalam setiap bulan berjalan dan kehadiran peserta didik direkap dengan menggunakan Kaizala.

Video conference (Vicon) merupakan telekomunikasi interaktif yang memungkinkan komunikasi antara dua orang atau lebih di lokasi yang berbeda sehingga dapat berinteraksi melalui pengiriman dua arah video dan audio bersamaan secara online. Vicon melibatkan pendidik dan peserta didik berinteraksi secara bersamaan, meski berada di lokasi yang berbeda. Selama pembelajaran pendidik dan peserta didik berkomunikasi melalui video dan dapat melihat (bertatapan muka) dan mendengar satu sama lain menggunakan laptop ataupun smartphone android. Keuntungan dari vicon dapat memonitor pembelajaran secara langsung di lapangan tanpa memonitoring dari satu lokasi ke lokasi yang lain (Seran et al., 2020). Manfaat dari video conference dalam PJJ ini adalah membantu warga beajar 
berinteraksi sehingga pembelajaran menjadi efektif dan efisien (Wibawanto, 2020).

Pertemuan daring di SMAN Unggul Aceh Timur dilakukan selama dua jam pelajaran atau setara 60 menit setiap pekan. Selebihnya dapat dilakukan melalui penugasan seperti menyimak video maupun pemberian soal latihan. Sementara untuk media penilaian atau evaluasi belajar digunakan aplikasi kuis online seperti Microsoft Forms, Kahoot, dan Quiziz.

Hasil pantauan penulis sebagai guru pengampu mata pelajaran kimia, pada saat meeting dilaksanakan, terdapat beberapa tantangan dan kendala. Seperti, sering terjadi gangguan suara, terutama apabila jaringan internet tidak stabil. Peserta didik kerap mematikan video kamera dan mikrofon. Mereka kurang memberikan respon atau pendapat pada saat guru menanyakan sesuatu hal. Akibatnya pembelajaran terkesan monoton karena interaksi yang terjadi hanya satu arah. Disamping hal tersebut, jumlah peserta didik yang menyerahkan tugas tepat waktu juga sangat sedikit sekali.

Susilawati (2020) mengungkapkan bahwa maraknya penggunaan pembelajaran online di masa pandemi mempunyai beberapa permasalahan seperti kurang intensnya interaksi antara pendidik dan peserta didik, serta peserta didik dengan peserta didik lainnya. Idealnya proses pembelajaran merupakan suatu proses yang mengandung serangkaian perbuatan pendidik dan peserta didik atas dasar hubungan timbal balik yang berlangsung dalam situasi edukatif untuk mencapai tujuan baik secara tatap muka langsung maupun menggunakan perantara media daring seperti saat ini (Razaq, 2014). Konsep dasar pembelajaran sesuai dengan Undang-Undang Nomor 20 Tahun 2003 tentang Sistem Pendidikan Nasional adalah proses interaksi peserta didik dengan pendidik dan sumber belajar pada suatu lingkungan belajar. Dalam konsep tersebut terkandung 4 unsur yakni pertama, interaksi dapat diartikan sebagai metode mengajar, kedua adalah manusia (pendidik dan peserta didik), ketiga sumber belajar (dapat berupa alat dan bahan pelajaran), dan keempat adalah lingkungan belajar, yaitu tempat di mana proses pembelajaran berlangsung. 
Jadi, dapat dipahami bahwa keberhasilan pembelajaran dipengaruhi oleh salah satu unsur pendidikan, yaitu keaktifan peserta didik. Keaktifan peserta didik ditunjukkan dengan partisipasinya. Partisipasi menurut (Suryosubroto, 2002) adalah keterlibatan mental dan emosi serta fisik anggota dalam memberikan inisiatif terhadap kegiatan-kegiatan yang dilancarkan oleh organisasi serta mendukung pencapaian tujuan dan bertanggung jawab atas keterlibatannya.

Partisipasi belajar peserta didik berarti keterlibatan peserta didik dalam kegiatan belajar yang diindikasikan dengan perilaku fisik dan psikisnya. Partisipasi tersebut dapat dilihat dari beberapa perilaku seperti mendengarkan, mendiskusikan, membuat sesuatu, menulis laporan, dan sebagainya (Hasibuan JJ, 2006). Senada dengan Silberman, (2006) yang menyatakan bahwa cara untuk mengaktifkan peserta didik adalah dengan pembentukaan kemitraan belajar, metode yang sesuai dengan kondisi mata pelajaran dan peserta didik, memotivasi peserta didik, pemilihan tugas, memfasilitasi diskusi, bereksperimen, bermain peran, efektivitas waktu belajar, dan pengendalian peserta didik yang berlebihan (hiperaktif).

Faktor utama munculnya partisipasi siswa dalam pembelajaran adalah adanya motivasi pembelajar yang akan memungkinkan mereka untuk berpartisipasi. Motivasi terdiri atas beberapa indikator diantaranya ialah (1) adanya hasrat dan keinginan untuk berbuat, (2) adanya dorongan dan kebutuhan melakukan kegiatan, (3) adanya harapan dan cita-cita, serta penghargaan dan penghormatan atas diri, (4) adanya lingkungan yang baik, dan (5) adanya kegiatan yang menarik (Sumiyati dkk., 2016). Selanjutnya Budiarjo, (2008) menyebutkan bahwa partisipasi siswa memuat beberapa indikator, yaitu (1) memperhatikan penjelasan guru, (2) aktif mengerjakan soal atau menjawab pertanyaan guru, (3) mengemukakan pendapat atau gagasan dalam berdiskusi, dan (4) menyimpulkan materi pembelajaran.

Oleh karena itu, untuk meminimalkan permasalahan yang telah diungkapkan di atas, maka penulis menawarkan sebuah alternatif tindakan yaitu dengan menggunakan metode pembelajaran tajak sare. Tajak sare adalah singkatan dari tanyajawab, koreksi, sharing, dan repetisi. 
Metode tanya jawab adalah teknik penyampaian pelajaran oleh guru, dimana guru memberikan pertanyan dan siswa menjawab dan sebaliknya siswa bertanya dan guru menjawab (Huda, 2020). Menurut (Daryanto, 2009) tanyajawab adalah suatu cara penyajian pelajaran dalam bentuk pertanyaan yang harus dijawab, terutama dari penyaji kepada peserta tetapi dapat pula dari peserta kepada penyaji. Tanyajawab adalah bagian yang penting dari pelajaran karena alasan: Pertama, tanyajawab memungkinkan guru mengetahui kondisi awal pengetahuan peserta didik dan memberikan informasi yang dibutuhkan untuk memutuskan apakah topik tertentu wajib diulang atau dilanjutkan ke tingkatan berikutnya. Dalam tanyajawab guru menyajikan serangkaian pertanyaan yang sifatnya menuntun dan menggali pengetahuan peserta didik sehingga terjadi proses asimilasi, akomodasi, dan equlibrasi pada dimensi kognitifnya (Fahris \& Wanarti, 2013).

Koreksi merupakan klarifikasi dan verifikasi yang dilakukan oleh guru terhadap tanggapan peserta didik atas permasalahan yang diberikan guru (Setiawan, 2019). Teknik koreksi secara langsung merupakan suatu pembetulan, perbaikan, atau pemeriksaan secara langsung untuk menilai pendapat siswa dihadapan siswa tersebut yang dilakukan oleh guru untuk mengevaluasi hasil dari siswa. Teknik koreksi dalam metode pembelajaran adalah merupakan bentuk penguatan (reinforcement) sebagai bentuk atas respon dari jawaban atau tanggapan siswa dalam pembelajaran. Firman (2019) memberikan penjelasan bahwa penguatan adalah aneka bentuk respons, baik bersifat verbal maupun non verbal, sebagai bagian dari modifikasi perlakuan guru terhadap siswa, yang bertujuan untuk mendapatkan informasi atau umpan balik (feed back) bagi siswa. Penguatan merupakan respon terhadap tingkah laku yang dapat meningkatkan kemungkinan berulangnya kembali tingkah laku tersebut. Teknik pemberian penguatan dalam proses pembelajaran yang bersifat verbal dapat dinyatakan melalui pujian, penghargaan atau pun persetujuan, sedangkan penguatan non verbal dapat dinyatakan melalui gesture, mimik muka (ekspresi), penguatan dengan cara mendekati, penguatan dengan sentuhan (contact), penguatan dengan kegiatan yang menyenangkan 
Sharing adalah kegiatan berbagi informasi dari peserta didik atau guru atas hasil kebenaran dari tahap koreksi. Sharing atau berbagi dalam tahapan pembelajaran melibatkan peran serta dari guru maupun peserta didik. Berbagi informasi merupakan tahapan komunikasi interpersonal diantara peserta didik. Komunikasi merupakan proses penyampaian pesan oleh seseorang kepada orang lain untuk memberi tahu, merubah sikap, pendapat atau perilaku baik langsung secara lisan maupun tak langsung melalui media. Dalam komunikasi terjadi hubungan timbal balik antara komunikator dan komunikan (Effendy, 2007). Komunikasi interpersonal merupakan proses komunikasi yang berlangsung antara dua orang atau lebih untuk berbagi pesan dan tanggapan dua arah secara langsung (Cangara, 2008).

Sementara repetisi ialah proses pengulangan dalam pembelajaran baik secara langsung diucapkan maupun dilakukan dengan pemberian latihan. Repetisi atau pengulangan dalam konteks pembelajaran merujuk pada pendalaman, perluasan, dan pemantapan siswa dengan cara memberi tugas atau kuis. Pembelajar akan terbiasa menyelesaikan persoalan-persoalan pembelajaran dan akan senantiasa siap dalam menghadapi tes ujian. Menurut Shoihimin (2014) repetition merupakan pengulangan, dengan tujuan memperdalam dan memperluas pemahaman siswa yang perlu dilatih melalui pengerjaan soal, pemberian tugas, dan kuis. Pengulangan dalam pembelajaran dimaksudkan agar pemahaman siswa lebih mendalam, disertai pemberian soal dalam bentuk tugas latihan atau kuis. Dengan pemberian tugas, diharapkan siswa lebih terlatih dalam menggunakan pengetahuan yang didapat dalam menyelesaikan soal dan mengingat apa yang telah diterima. Sementara pemberian kuis dimaksudkan agar siswa siap menghadapi ujian atau tes yang dilaksanakan sewaktu-waktu serta melatih daya ingat. Bila guru menjelaskan suatu konsep, maka perlu diulang karena ingatan siswa tidak selalu tetap dan mudah lupa. Pelajaran yang diulang akan memberikan tanggapan yang jelas, dan tidak mudah dilupakan, sehingga dapat diberikan secara teratur, pada waktu-waktu tertentu atau setelah tiap unit diberikan, maupun secara insidentil jika dianggap perlu. 
Berdasarkan uraian di atas maka dapat dirangkaian langkah-langkah dalam metode pembelajaran tajak sare adalah sebagai berikut; (a) Guru menjelaskan kepada peserta didik tujuan pembelajaran; (b) Guru mengkomunikasikan penggunaaan metode tanyajawab (siswa tidak hanya bertanya tetapi juga menjawab pertanyaan guru maupun siswa yang lain); (c) Guru memberikan permasalahan sebagai bahan apersepsi; (d) Guru menguraikan topik materi pembelajaran; (e) Guru mengajukan pertanyaan keseluruh kelas; (f) Guru meminta beberapa peserta didik untuk menjawab pertanyaan yang disampaikan; (g) Guru mengarahkan peserta didik lainnya untuk memberikan jawaban; (h) Guru mengarahkan peserta didik untuk memberikan sanggahan atau pendapat atas jawaban dari peserta didik lain; (i) Guru memberikan penguatan atau koreksi atas jawaban dan pendapat peserta didik; (j) Peserta didik diarahkan kembali untuk berbagi informasi atas topik tersebut; dan (k) Guru memberikan tugas diakhir pembelajaran sebagai bahan evaluasi belajar.

Penelitian sebelumnya menunjukkan bahwa penerapan metode tanyajawab dapat meningkatkan hasil belajar IPA siswa dengan rata-rata 82.3 menjadi sebanyak 85 pada siklus ke dua (Sitohang, 2017). Demikian juga dengan hasil penelitian yang dilakukan Zainullah (2010), menyimpulkan bahwa proses metode tanyajawab probing prompting dapat mengaktifkan peserta didik dalam belajar yang penuh tantangan, membutuhkan konsentrasi dan keaktifan sehingga aktivitas komunikasi pembelajaran cukup tinggi. Sedangkan pada penelitian yang dilakukan Jubaedah (2008) menyimpulkan bahwa pembelajaran tanyajawab Probing-Prompting lebih baik dari pada pembelajaran konvensional.

\section{B. Metode}

Prosedur penelitian mengacu kepada prosedur peneltian tindakan model Kemmis S. and Mc. Taggart yang melalui beberapa langkah yaitu perencanaan, pelaksanaan, pengamatan, dan refleksi. Penelitian dilaksanakan dalam 2 siklus tindakan. Lokasi penelitian dilaksanakan di kelas daring 
Microsoft Teams XII MIPA 1 SMA Negeri Unggul Aceh Timur. Peserta didik berada di rumah masing-masing dan guru berada di ruangan guru di sekolah.

Penelitian dinyatakan berhasil jika persentase peserta didik dalam setiap indikator pengamatan telah melampaui rerata partisipasi kelas dalam 2 siklus tindakan yang telah dilaksanakan atau 75\% partisipasi klasikal telah memenuhi dari indikator yang diamati. Dalam penelitian ini pengumpulan data dilakukan dengan menggunakan instrumen non tes untuk memperoleh data mengenai partisipasi peserta didik selama mengikuti pembelajaran. Selain itu juga melalui observasi oleh pengamat melalui catatan-catatan untuk memperoleh data mengenai aktivitas guru dan peserta didik selama berlangsungnya proses pembelajaran dengan metode tajak sare.

Instrumen penelitian yang digunakan adalah observasi untuk melihat tingkat partisipasi peserta didik. Instrumen penelitian dikembangkan dari indikator partisipasi belajar peserta didik yakni; (1) Memperhatikan penjelasan guru; (2) Menjawab pertanyaan guru; (3) Memberikan sanggahan/pendapat; dan (4) Menyelesaikan tugas tepat waktu. Analisis data dilakukan dengan menggunakan statistik deskriptif. Tujuannya adalah untuk memaparkan hasil perolehan data jumlah peserta didik yang memenuhi indikator partisipasi peserta didik dalam proses pembelajaran.

\section{Hasil dan Pembahasan}

\section{Hasil}

Semenjak pembelajaran dilaksanakan dengan pembelajaran daring dengan memanfaatkan LMS Microsoft Teams dengan penjadwalan Video Conference sebagai pengganti proses belajar tatap muka, teknik pembelajaran terkesan menjadi monoton maupun satu arah seperti pelaksanaan seminar/webinar. Tingkat partisipasi siswa dalam mengikuti pembelajaran cenderung rendah. Hal ini tampak dari sedikitnya peserta didik yang menghidupkan kamera video pada saat guru menerangkan yakni hanya sekitar 7 orang peserta saja (25.93\%), jika guru bertanya yang menjawab hanya 5 orang peserta (18.52\%), dan peserta didik yang memberikan pendapat hanya sekitar 4 orang saja (14.81\%), dan sedikitnya 
peserta didik yang tepat waktu dalam pengumpulan tugas dari guru yakni sekitar 8 orang atau $29.63 \%$.

\section{a. Deskripsi Hasil Siklus 1}

Tahap perencanaan dalam penelitian tindakan ini meliputi penyusunan RPP dengan metode tajak sare dengan kompetensi dasar menganalisis proses yang terjadi dalam sel Volta dan menjelaskan kegunaannya, kemudian menyiapkan bahan ajar berupa slide power point, serta menyusun lembar observasi peserta didik. Tindakan pada siklus 1 terdiri dari 4 pertemuan, dimana pada setiap pertemuan peneliti menerapkan pembelajaran daring dengan metode tajak sare melalui LMS Microsoft Teams berbantuan video conference (vicon). Untuk kegiatan vicon dilakukan sebanyak 2 kali berselang setiap pekannya. Metode tajak sare dalam penerapannya sendiri dilakukan dengan teknik guru memberikan materi ajar terlebih dahulu melalui presentasi kemudian meminta peserta didik untuk bertanya, lalu mengalihkan kepada peserta lain untuk menjawab dan atau menyanggah pendapat temannya kemudian memberikan koreksi kepada jawaban peserta didik sebagai penguatan. Informasi yang sudah benar disampaikan secara klasikal kepada peserta oleh guru. Diakhir pembelajaran hasil simpulan diulang kembali sebagai bahan informasi bagi seluruh peserta didik. Selama proses pembelajaran dengan vicon peneliti mengumpulkan data pengamatan untuk mengetahui tingkat partisipasi peserta didik. Hasil yang diperoleh selama observasi pembelajaran siklus 1 pada tahap tindakan selama dua pertemuan vicon disajikan dalam tabel sebagai berikut; 
Tabel 1 Hasil Pengamatan Partisipasi Peserta didik Siklus 1

\begin{tabular}{llcccc}
\hline \multirow{2}{*}{ No. } & \multirow{2}{*}{ Indikator Partisipasi } & \multicolumn{3}{c}{ Jumlah(N = 27) } & \multirow{2}{*}{$\%$} \\
\cline { 3 - 5 } & & Vicon 1 & Vicon 2 & Rerata & \\
\hline 1 & Memperhatikan penjelasan guru & 12 & 13 & 12,5 & 46,30 \\
2 & Menjawab pertanyaan guru & 7 & 9 & 8 & 29,63 \\
3 & Memberikan sanggahan/pendapat & 7 & 8 & 7,5 & 27,78 \\
4 & Menyelesaikan tugas tepat waktu & 13 & 13 & 13 & 48,15 \\
\hline \multicolumn{3}{c}{ Rerata Persentase } & & $\mathbf{3 7 , 9 6}$ \\
\hline
\end{tabular}

Dari tabel 1 diketahui bahwa jumlah peserta didik yang memperhatikan penjelasan guru adalah $46,30 \%$ dari keseluruhan peserta didik, yang menjawab pertanyaan guru hanya 29,63 \%; peserta didik yang memberikan sanggahan/pendapat adalah $27,78 \%$; dan peserta didik yang menyelesaikan tugas tepat waktu hanya $48,15 \%$.

\section{b. Deskripsi Hasil Siklus 2}

Pada siklus kedua dengan tujuan pembelajaran menentukan urutan kekuatan pengoksidasi atau pereduksi pada pertemuan pertama dan merancang sel volta dengan menggunakan bahan sekitar. RPP disusun sedemikian rupa beserta bahan ajar berupa slide presentasi. Dalam penerapan tindakan dengan menggunakan metode tajak sare, teknik bertanya dan memberikan jawaban sedikit diubah, dari yang semula pertanyaan bewrsumber dari guru, maka pada siklus kedua ini pertanyaan diminta berasal dari peserta didik. Dimana peserta didik lainnya diminta secara bergantian sebagai narasumber dari tugas yang diberikan guru sebelumnya. Sehingga diharapkan ada interaksi yang lebih aktif diantara peserta didik tersebut. Peneliti sendiri menyiapkan beberapa pertanyaan arahan sebagai panelis pada proses pembelajaran. Hasil jawaban dan sanggahan dari peserta didik dikoreksi guru kembali sebagai penguatan, kemudian dibagi kepada seluruh peserta secara klasikal, dan ditarik suatu kesimpulan ulangan di akhir pembelajaran. Hasil pengamatan partisipasi peserta didik pada siklus 2 dapat dilihat pada tabel berikut ini. 
Tabel 2 Hasil Pengamatan Partisipasi Peserta didik Siklus 2

\begin{tabular}{llcccc}
\hline \multirow{2}{*}{ No. } & \multirow{2}{*}{ Indikator Partisipasi } & \multicolumn{3}{c}{ Jumlah(N = 27) } & \multirow{2}{*}{$\%$} \\
\cline { 3 - 5 } & & Vicon 1 & Vicon 2 & Rerata & \\
\hline 1 & Memperhatikan penjelasan guru & 18 & 23 & 20,5 & 75,93 \\
2 & Menjawab pertanyaan guru & 16 & 19 & 17,5 & 64,81 \\
3 & Memberikan sanggahan/pendapat & 11 & 14 & 12,5 & 46,30 \\
4 & Menyelesaikan tugas tepat waktu & 18 & 20 & 19 & 70,37 \\
\hline \multicolumn{3}{c}{ Rerata Persentase } & & $\mathbf{6 4 , 3 5}$ \\
\hline
\end{tabular}

Berdasarkan tabel 2, dapat diketahui bahwa persentase peserta didik yang memperhatikan penjelasan guru adalah sebesar 75,93\%; pada indikator menjawab pertanyaan guru sebanyak 64,81\%; memberikan sanggahan/pendapat sebesar 46,30\%; dan menyelesaikan tugas tepat waktu adalah sebesar 70,37 \%. Jika kita bandingkan persentase indikator dengan persentase rerata maka dapat diketahui indikator memberikan sanggahan/ pendapat masih berada dibawah rerata partispasi klasikal.

\section{c. Perbandingan Hasil Siklus 1 dan Siklus 2}

Jika dibandingkan hasil pengamatan antara siklus 1 dan siklus 2 maka dapat dilihat pada tabel di bawah ini;

Tabel 3 Perbandingan Partisipasi Belajar Antara Siklus 1 dan Siklus 2

\begin{tabular}{llccc}
\hline \multirow{2}{*}{ No } & \multirow{2}{*}{ Indikator Partisipasi } & \multicolumn{2}{c}{ Persentase } & \multirow{2}{*}{ \% } \\
\cline { 3 - 4 } & & Siklus 1 & Siklus 2 & \\
\hline $\mathbf{1}$ & Memperhatikan penjelasan guru, & 46,30 & 75,93 & 29,63 \\
$\mathbf{2}$ & Menjawab pertanyaan guru, & 29,63 & 64,81 & 35,19 \\
$\mathbf{3}$ & Memberikan sanggahan/ pendapat & 27,78 & 46,30 & 18,52 \\
$\mathbf{4}$ & Menyelesaikan tugas tepat waktu & 48,15 & 70,37 & 22,22 \\
\hline \multirow{2}{*}{} & Rerata Persentase & $\mathbf{3 7 , 9 6}$ & $\mathbf{6 4 , 3 5}$ & $\mathbf{2 6 , 3 9}$ \\
\hline
\end{tabular}


Berdasarkan tabel tersebut dapat diketahui bahwa terjadi peningkatan partisipasi peserta didik dari setiap indikator pengamatan. Secara keseluruhan dari siklus 1 ke siklus 2 terjadi peningkatan partisipasi secara klasikal sebesar 26,39 \%. Dimana terjadi peningkatan dari 46,30\% menjadi $75,93 \%$ pada indikator memeperhatikan penjelasann guru. Kemudian indikator menjawab pertanyaan guru meningkat dari $29,63 \%$ menjadi $64,81 \%$. Sementara pada indikator memberikan sanggahan/pendapat terjadi peningkatan dari 27,78\% menjadi 70,37\%; dan pada indikator menyelesaikan tugas tepat waktu meningkat dari 48,15\% menjadi 70,37\%. Selanjutnya peningkatan indikator partisipasi tersebut dapat disajikan pada diagram di bawah ini;

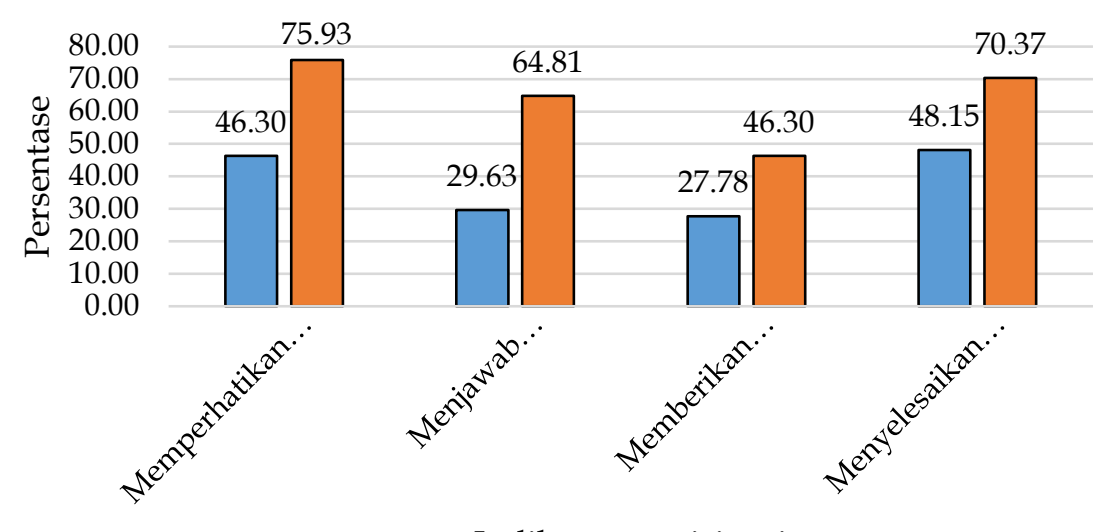

Indikator partisipasi

$\square$ Siklus $1 \quad \square$ Siklus 2

Gambar 1 Diagram Peningkatan Partisipasi dari siklus 1 ke siklus 2

\section{Pembahasan}

Pembelajaran daring dengan memanfaatkan LMS Microsoft Teams dengan pembelajaran vicon terjadwal per pekannya yang dilakukan pada awal tahun pelajaran 2020/2021 di SMAN Unggul Aceh Timur dilakukan dengan pola pembelajaran webinar atau seminar berbasis web. Biasanya guru memberikan uraian materi kemudian peserta didik memperhatikan penjelasan guru. Di akhir topik biasanya dibuka sesi tanyajawab dengan peserta didik. Namun metode pembelajaran daring dengan vicon seperti ini memberikan kesan bosan bagi peserta didik sehingga berdampak pada 
kurangnya tingkat partisipasi belajar dari peserta didik yakni hanya sebesar $22,22 \%$. Faktor-faktor yang menjadi penyebab rendahnya partisipasi ini bisa diasumsikan bahwa belum terbiasanya peserta didik dengan pola pembelajaran daring, karakter peserta didik XII MIPA 1 yang cenderung pasif (pendiam) kemandirian belajar yang masih rendah, metode pembelajaran yang belum dapat menarik perhatian peserta didik secara daring.

Berdasarkan tindakan yang dilakukan pada siklus 1, peneliti berfokus pada empat indikator utama partisipasi siswa dengan menerapkan metode tajak sare dalam pembelajaran. Tindakan utama pada siklus 1 adalah dengan mengarahkan peserta didik untuk memperhatikan penjelsan guru dengan tidak mematikan kamera video, kemudian memberikan pertanyaanpertanyaan kepada peserta didik, mengarahkan peserta didik untuk memberikan jawaban, sanggahan maupun pendapat terhadap topik pelajaran pada hari tersebut. Hasil pengamatan peneliti tampak peserta didik sudah mulai berpartisipasi dari pada kondisi sebelumnya, dengan persentase secara keseluruhan adalah 37,96\%. Namun jika diukur dengan indikator keberhasilan masih terdapat 2 indikator yang berada dibawah rerata partispasi kelas yakni menjawab pertanyaan guru dan memberikan pendapat atau sanggahan. Sehingga peneliti melakukan tindakan pada siklus berikutnya.

Pada siklus kedua, peneliti masih menerapkan metode tajak sare. Namun pada kegiatan inti sedikit diberikan perubahan pola tindakan yaitu setelah guru memberikan orientasi pelajaran, peserta didik secara bergiliran diberikan kesempatan untuk menjelaskan konsep materi yang telah ditugaskan sebelumnya, sementara peserta didik lainnya menyimak penjelasan tersebut, kemudian dibuka sesi tanyajawab langsung diantara peserta didik, dimana guru hanya berperan sebagai panelis kegiatan. Hasil pengamatan peneliti pada siklus kedua dari 2 pertemuan vicon, dapat dilihat bahwa terjadi peningkatan dari partisipasi dari siklus 1 yakni sebesar 26,39\% dari persentase siklus 1 yang mencapai 37,96\% secara keseluruhan menjadi $64,35 \%$ pada tingkat partisipasi klasikal.

Sesuai dengan uraian di atas maka terjadi peningkatan baik secara indikator maupun secara keseluruhan dari partisipasi peserta didik kelas XII 
MIPA 1. Namun masih terdapat satu indikator yang berada dibawah rerata partipasi klasikal yakni indikator memberikan pendapat/ sanggahan, yaitu 46,30\% yang berada dibawah rerata partispasi klasikal siklus 2 yakni 64,35\%. Merujuk pada pembahasan di atas maka 3 indikator partispasi dari 4 indikator partispasi yang diamati pada siklus 2 telah berada di atas rerata partisipasi klasikal. Sehingga tindakan dalam penelitian ini dinyatakan telah memenuhi indikator keberhasilan. Demikian pun peneliti tetap merekomendasikan untuk melaksakan tindakan yang lebih efektif dalam pembelajaran daring untuk meningkatkan partisipasi peserta didik, terutama untuk meningkatan indikator pemberian pendapat/ sanggahan.

\section{Kesimpulan}

Penerapan metode tajak sare dalam pembelajaran daring pada mata pelajaran kimia dapat meningkatkan partisipasi peserta didik. Hal ini ditunjukkan dengan adanya peningkatan persentase partispasi klasikal dari $37,96 \%$ pada siklus pertama menjadi $64,35 \%$ pada siklus kedua.

\section{DAFTAR PUSTAKA}

Budiarjo, M. (2008). Dasar-dasar ilmu politik. Gramedia Pustaka Utama.

Cangara, H. (2008). Pengantar Ilmu Komunikasi. Raja Grafindo Persada.

Crockett, M., \& Foster, J. (2005). Paket Bahan Pelatihan bagi Instruktur. ICA Section on Archival Education and Training. http://www.icasae.org/trainer/indonesian/index.htm

Daryanto. (2009). Panduan proses pembelajaran kreatif dan inovatif. Publisher.

Effendy, 0. (2007). Ilmu Komunikasi Teori dan Praktek. Remaja Rosdakarya.

Fahris, M., \& Wanarti, P. (2013). Pengaruh Metode Pembelajaran Tanya Jawab Probing-Prompting Terhadap Hasil Belajar Siswa Pada Standar Kompetensi Menerapkan Dasar-Dasar Elektronika Kelas X Av Di Smk Negeri 2 Surabaya. Jurnal Pendidikan Teknik Elektro, 3(1).

Firman, A. (2019). 8 Keterampilan Dasar Mengajar ini Yang Harus Dikuasai Guru. $\quad$ https://komputergrafis01.blogspot.com/2019/08/8keterampilan-dasar-mengajar-yang.html 
Hasibuan JJ, M. (2006). Proses Belajar Mengajar. CV. Remaja Rosdakarya.

Huda, N. (2020). Penerapan metode tanya jawab sebagai upaya meningkatkan keaktifan siswa pada mata pelajaran fiqih kelas X IPA 3 MA Darussalam Krempyang Tanjunganom Nganjuk. Jurnal El-Barqie: Jurnal MA Darussalam, 1, 141-162.

Jubaedah, E. (2008). Penerapan Metode Tanya-Jawab dengan Teknik ProbingPrompting Untuk Meningkatkan Kemampuan Berpikir Kritis Siswa Di Kelas XI IPA 4 SMA Negeri 14 Bandung.

Razaq, A. R. (2014). Interaksi pembelajaran efektif untuk berprestasi. Jurnal Pilar, 2(2), 122-136.

Rinaldi, A. A., Daryati, D., \& Arthur, R. (2017). Penggunaan Media Pembelajaran Berbasis Audio Visual untuk Mata Pelajaran Konstruksi Bangunan. Jurnal PenSil, 6(1), 1-7. https://doi.org/10.21009/jpensil.v6i1.7231

Seran, W. A., Utomo, D. H., \& Handoyo, B. (2020). Pengaruh Model Pembelajaran Outdoor Study Berbantuan Video Conference terhadap Kemampuan Menulis Karya Ilmiah Mahasiswa. Jurnal Pendidikan, 5(2), 142-152.

Setiawan, E. (2019). Kamus Besar Bahasa Indonesia. Kemdikbud. https://kbbi.web.id/

Shoihimin, A. (2014). 68 Model pembelajaran inovatif dalam kurikulum 2013. Ar Ruzz Media.

Silberman, M. (2006). Active Learning : 101 Cara Belajar Siswa Aktif. Nuansa.

Sitohang, J. (2017). Penerapan metode tanya jawab untuk meningkatkan hasil belajar ipa pada siswa sekolah dasar. Suara Guru : Jurnal Ilmu Pendidikan Sosial, Sains, Dan Humaniora, 3(4), 681-688.

Sofyana, L., \& Rozaq, A. (2019). Pembelajaran daring kombinasi berbasis Whatsapp pada kelas karyawan Prodi Teknik Informatika Universitas PGRI Madiun. Jurnal Nasional Pendidikan Teknik Informatika (JANAPATI), 8(1), 81. https://doi.org/10.23887/janapati.v8i1.17204

Sumiyati, Fauziah, R., \& Makarim, H. (2016). Hubungan Antara Motivasi Mengikuti Ekstrakurikuler Sains Dengan Partisipasi Siswa Dalam Pembelajaran Ipa. Didaktika Tauhidi, 3(1), 26-38.

Suryosubroto. (2002). Proses belajar mengajar di sekolah. Rineka Cipta. 
Susilawati, E. (2020). UPAYA MENINGKATKAN KEAKTIFAN MAHASISWA DALAM MENGANALISIS Covid-19.13(October).

Wibawanto, T. (2020). Pemanfaatan Video Conference Dalam Pembelajaran Tatap Muka Jarak Jauh Dalam Rangka Belajar Dari Rumah. http://lpmplampung.kemdikbud.go.id/detailpost/pemanfaatan-videoconference-dalam-pembelajaran-tatap-muka-jarak-jauh-dalam-rangkabelajar-dari-rumah

Zainullah. (2010). Penerapan metode pembelajaran probing promting pada mata pelajaran IPA kelas IV SDN palangsari II kecamatan Puspo kabupaten Pasuruan. In Handout. Jurusan Pendidikan Matematika UNM.

Zhafira, N. H. (2020). Daring sebagai sarana pembelajaran selama masa karantina Covid-19. Jurnal Bisnis Dan Kajian Strategi Manajemen, 4, 3745. 
